\title{
Genotype by Trait Associations among Drought Tolerant Maize Inbred Lines
}

\author{
Cousin Musvosvi ${ }^{1,2} \&$ Mruthunjaya C. Wali ${ }^{1}$ \\ ${ }^{1}$ Department of Genetics and Plant Breeding, University of Agricultural Sciences, Dharwad, Karnataka, India \\ ${ }^{2}$ School of Agricultural, Earth and Environmental Sciences, Life Science Campus, University of KwaZulu-Natal, \\ Scottsville, Pietermaritzburg, KwaZulu Natal, South Africa \\ Correspondence: Cousin Musvosvi, School of Agricultural, Earth and Environmental Sciences, Life Science \\ Campus, University of KwaZulu-Natal, Private Bag X01, Scottsville, 3209, Pietermaritzburg, KwaZulu Natal, \\ South Africa. E-mail: cousinmusvosvi@yahoo.co.uk
}

Received: September 10, 2017

Accepted: October 24, 2017

Online Published: November 15, 2017

doi:10.5539/jas.v9n12p21

URL: https://doi.org/10.5539/jas.v9n12p21

\begin{abstract}
Twelve tropical, yellow maize inbred lines identified as drought tolerant were evaluated in multi environments, including managed drought, rain fed and irrigated conditions. The objective was to study genotype-trait associations across environments. A $3 \times 4 \alpha$-lattice design with two replications was used in each environment. Data were recorded for twenty-one traits. Combined analysis of variance using data from all environments was done for all traits using the GLM procedure in SAS version 9.3. Genotype by trait associations were revealed using the genotype main effect plus genotype-by-environment biplot model in GENSTAT $14^{\text {th }}$ Edition. Inbred lines which were associated with high grain yield and related desirable traits such as a low drought susceptibility index under managed drought were DMR-M-81, DMR-M-88, FA6, GPM36 and M39. Across the diverse environments, DMR-M-84, DMR-M-88, FA6 and GPM36 were associated with grain yield and/or its related traits. The inbred lines associated with desirable traits could be evaluated for combining ability in order to know their desirability in cultivar development. These inbred lines could be used as female parents in seed production programmes since high productivity and drought tolerance are important qualities of female parents in seed production.
\end{abstract}

Keywords: maize (Zea mays L.), inbred lines, drought tolerance, trait profiles

\section{Introduction}

Drought is the most important abiotic constraint to maize grain production worldwide, where most of the 160 million hectares which is put under maize is rainfed (Bänziger, Edmeades, Beck, \& Bellon, 2000; Edmeades, 2013). Development of drought tolerant maize germplasm is critical to alleviate drought impacts on maize production (Edmeades, 2013). In breeding drought tolerant maize hybrids that would sustain production under climatic changes, identification of parents and knowing their attributes through characterization is a prerequisite (Chen, Xu, Velten, Xin, \& Stout, 2012). There is evidence that use of drought tolerant inbred lines in hybrid development can lead to a significantly higher proportion of hybrid progenies that exhibit good performance under drought and other stresses like low soil nitrogen (Betrán, Beck, Bänziger, \& Edmeades, 2003; Meseka, Menkir, Ibrahim, \& Ajala, 2013), and this indicate the importance of the inbred-hybrid approach in developing stress tolerant hybrids (Kirkham, Suksayretrup, Wassom, \& Kanemasu, 1984).

Genotype by trait biplot analysis is an application of the genotype plus genotype $\times$ environment interaction (GGE) biplot technique (Yan, Hunt, Sheng, \& Szlavnics, 2000) and can be used for analysis of multi-trait data (Yan \& Kang, 2003). Using this method, the data in a genotype by trait table can be displayed as a biplot, thereby exhibiting trait associations (Yan \& Rajcan, 2002), as well as genotype trait profiles (Yan \& Kang, 2003; Yan \& Fregeau-Reid, 2008). This tool has been used to evaluate genotypes and explore trait associations in various crops as reported by Yan and Rajcan (2002), Rubio, Cubero, Martin, Suso, and Flores (2004), Oladejo, Akinwale and Obisesan (2011), and other authors. A study of genotype by trait associations among maize inbred lines using biplots can be used to visualize trait profiles of particular genotypes which helps in knowing their strengths and weaknesses, and this technique can be utilized in selection of parents in a breeding programme (Yan \& Fregeau-Reid, 2008; Yan \& Kang, 2003; Yan \& Tinker, 2006). Twelve tropical yellow maize inbred lines 
that were selected for drought tolerance in a 2011-2012 drought screening trial (unpublished) were used in this study. The objective was to study genotype by trait associations among the inbred lines under drought and across environments.

\section{Materials and Methods}

\subsection{Germplasm and Environments}

Twelve maize inbred lines (Table 1) that were identified as drought tolerant in a 2011-2012 dry season drought screening trial were used in this study. All the inbred lines are maintained at University of Agricultural Sciences, Dharwad, under the All India Coordinated Maize Improvement Project (AICMIP). Three locations in Karnataka, India, were used for evaluation trials, and these are Agricultural Research Station (ARS) Arabhavi, ARS Bailhongal and Main Agricultural Research Station (MARS) Dharwad. There were a total of seven environments, and an environment was considered as a combination of location, season and water regime (Table 2).

Table 1. Twelve drought tolerant inbred lines that were evaluated in multi-environmental trials

\begin{tabular}{llll}
\hline Code & Inbred line & Pedigree & Origin \\
\hline G1 & DMR-M-81 & CI-4 & International Centre for Maize and Wheat Improvement (CIMMYT) \\
G2 & M4 & KDMI-16 & All India Coordinated Maize Improvement Project (AICMIP), ARS Arabhavi \\
G3 & FA6 & ARYP-73 & AICMIP, ARS Arabhavi \\
G4 & DMR-M-83 & CI-5 & CIMMYT \\
G5 & GPM36 & ARYP-36 & Indian Institute of Maize Research, ICAR, Winter nursery, Hyderabad (IIMR, Hyderabad) \\
G6 & DMR-M-88 & CM-501 & ICAR-Indian Institute of Maize Research (IIMR), New Delhi \\
G7 & DMR-M-84 & KDMI-10 & AICMIP, ARS Arabhavi \\
G8 & M39 & ARYP-39 & AICMIP, ARS Arabhavi \\
G9 & M53 & ARYP-53 & Zonal Agricultural Research Station, Mandya, University of Agricultural Sciences, Bengaluru \\
G10 & FA3 & ARYP-70 & AICMIP, ARS Arabhavi \\
G11 & GPM43 & ARYP-43 & IIMR, Hyderabad \\
G12 & GPM53 & ARYP-53 & IIMR, Hyderabad \\
\hline
\end{tabular}

Table 2. Description of environments used for evaluation of 12 drought tolerant maize inbred lines

\begin{tabular}{|c|c|c|c|c|c|c|c|}
\hline Code & Location & $\begin{array}{l}\text { Latitude } \\
\mathrm{N}\end{array}$ & $\begin{array}{l}\text { Longitude } \\
\text { E }\end{array}$ & $\begin{array}{l}\text { Altitude } \\
\text { (m) }\end{array}$ & Soil description & Season/water regime & Planting date \\
\hline E1 & ARS Arabhavi & 16 & 74.5 & 585.2 & Medium black clay loam of $\mathrm{pH} 8$ & $\begin{array}{l}\text { 2012-2013 dry season, } \\
\text { managed drought }\end{array}$ & 03-12-2012 \\
\hline E2 & ARS Arabhavi & 16 & 74.5 & 585.2 & Medium black clay loam of $\mathrm{pH} 8$ & $\begin{array}{l}\text { 2012-2013 dry season, } \\
\text { irrigated }\end{array}$ & 03-12-2012 \\
\hline E3 & ARS Arabhavi & 16 & 74.5 & 585.2 & Medium black clay loam of $\mathrm{pH} 8$ & $\begin{array}{l}2013 \text { rainy season, rain fed, } \\
\text { supplementary irrigation }\end{array}$ & $01-08-2013$ \\
\hline $\mathrm{E} 4$ & MARS Dharwad & 15.48 & 74.98 & 678 & Medium deep black clay loam of $\mathrm{pH} 7.5$ & 2013 rainy season, rain fed & 01-07-2013 \\
\hline E5 & ARS Bailhongal & 16 & 75.5 & 680 & Medium black, $\mathrm{pH}$ range is $7.2-8.4$ & 2013 rainy season, rain fed & $11-07-2013$ \\
\hline E6 & ARS Arabhavi & 16 & 74.5 & 585.2 & Medium black clay loam of $\mathrm{pH} 8$ & $\begin{array}{l}\text { 2013-2014 rainy season, } \\
\text { managed drought }\end{array}$ & 02-01-2014 \\
\hline E7 & ARS Arabhavi & 16 & 74.5 & 585.2 & Medium black clay loam of $\mathrm{pH} 8$ & $\begin{array}{l}\text { 2013-2014 rainy season, } \\
\text { irrigated }\end{array}$ & 02-01-2014 \\
\hline
\end{tabular}

\subsection{Trial Establishment and Management}

A $3 \times 4 \alpha$-lattice design with two replications was used under each evaluation environment. An experimental unit was a two-row three-metre long plot which was occupied by a particular genotype (inbred line). A spacing of 0.6 $\mathrm{m}$ between rows and $0.2 \mathrm{~m}$ between planting hills within a row was used. Two seeds were placed per hill during planting, but thinning was done at three weeks after planting to one plant per hill giving rise to a plant population 
of 83333 plants ha ${ }^{-1}$. In the managed drought stress trials, there was withdrawal of irrigation at 36 days after planting, and afterwards there was no more irrigation. This was done in order to impose drought stress at flowering and post-flowering stages. In the well-watered trial, irrigation water was applied after every 12 days to maintain optimal moisture conditions throughout the growing period. Fertilizer was applied at the following rates in all evaluation environments: $150 \mathrm{~kg} \mathrm{~N} h a^{-1}, 75 \mathrm{~kg} \mathrm{P} \mathrm{ha}^{-1}, 37.5 \mathrm{~kg} \mathrm{~K} \mathrm{ha}^{-1}$. At ARS Arabhavi, zinc sulphate was also applied at $10 \mathrm{~kg} \mathrm{ha}^{-1}$ since the soil at that site is deficient of zinc. The trials were kept weed free mainly by hand weeding. Inter-row cultivation was done using a bullock drawn cultivator at four and eight weeks after planting. All packages of best practices were used to raise a good crop.

\subsection{Data Collection}

Data for twenty-one traits were recorded on a plot basis. Days to anthesis were determined as the number of days from planting date to the date when $50 \%$ of plants in a plot had fully emerged tassels and shedding pollen. Days to silking were determined as the number of days from planting date to the date when $50 \%$ of plants in a plot had emerged silks. Anthesis-silking interval was calculated by subtracting days to anthesis from days to silking. Days to physiological maturity were determined as the number of days from planting date to the date when $75 \%$ of plants in a plot had dry cob husks. Grain filling duration was calculated by subtracting days to silking from days to physiological maturity. Leaf rolling was visually scored under drought at two weeks before flowering using a 1 to 5 scale, 1 representing unrolled leaves and 5 representing lax leaves. Leaf senescence was scored visually under drought conditions on a 1 to 10 scale, where 1 represented green leaves and 10 represented completely senesced leaves. Ear height was measured at physiological maturity as distance in centimetres from the base of the plant to the insertion of the top (uppermost) ear of the same plant and mean of six plants was recorded. Plant height was measured at physiological maturity as the distance in centimetres from base of plant to the first tassel branch of the same plant, and a mean of six plants was recorded. Tassel size was visually scored from the milk to dough stages of grain filling, on a 1 to 5 scale where 1 represented very small tassel with few branches and 5 represented a large tassel with many branches. Lodging was visually scored at maturity using a 1 to 5 scale where 1 represented no lodging of plants, and 5, extreme lodging. Ears per plant were determined by counting the number of ears with at least one kernel in a plot, and dividing by the total number of plants. Ear aspect was visually rated on a scale of 1 to 5, where 1 represented clean, uniform, large, and well-filled ears and 5, ears with most undesirable (diseased, insect damaged, small, partially filled, and variable) features. Ear length was determined as the measurement of the length of an ear in centimetres, and a mean length for six ears was recorded. Ear diameter was determined as the measurement of the maximum girth of the ear using vernier calipers and mean of six ears was recorded in centimetres. Kernel row number was observed in the central part of the ear and mean of six ears was recorded. Kernels per ear row was observed and a mean of six ears was recorded. Kernels per ear was counted manually and the average for six ears was recorded. Kernel weight per ear was determined by weighing shelled kernels from six ears and getting an average for a single ear. Grain yield was determined as kernel weight per plot in tons per hectare, adjusted to $15 \%$ moisture content. Drought susceptibility index for grain yield was calculated as follows:

$$
D S I=\left(\frac{1-Y s}{Y c}\right) /\left(\frac{1-Y s m}{Y c m}\right)
$$

Where, $Y_{S}$ is mean grain yield of a genotype under managed drought stress, $Y c$ is mean grain yield of the same genotype under well-watered conditions, Ysm is mean grain yield of all genotypes under managed drought stress, and $Y \mathrm{~cm}$ is mean grain yield of all genotypes under well-watered conditions.

\subsection{Data Analysis}

\subsubsection{Analysis of Variance}

The PROC GLM procedure of SAS 9.3 (SAS Institute, 2010) was used for analysis of variance. Combined data from all environments and for all traits observed across environments were subjected to analysis of variance. The LSMEANS statement was used to calculate adjusted means for the inbred lines, and the TUKEY option was used at $5 \%$ probability level when mean separation was necessary.

\subsubsection{Genotype by Trait Associations}

The genotype by trait associations were analysed following Yan and Rajcan (2002), using GENSTAT $14^{\text {th }}$ Edition (Payne et al., 2011). This was done using trait least square means under managed drought, and least squares means computed from across all environments. The GGE biplot model based on singular value decomposition was used to determine genotype by trait associations, and is presented as: 


$$
\left(Y_{i j}-\mu-\beta_{j}\right) / S_{j}=\lambda_{1} \xi_{i 1} \eta_{j 1}+\lambda_{2} \xi_{i 2} \eta_{j 2}+\varepsilon_{i j}
$$

Where, $Y_{i j}$ is the genetic value of the combination between genotype $i$ and trait $j, \mu$ is the grand mean, $\beta_{j}$ is the $j^{\text {th }}$ trait main effect, and $\mu+\beta_{j}$ is the mean across all genotypes for the $j^{\text {th }}$ trait (Yan \& Rajcan, 2002). The terms $\lambda_{1}$ and $\lambda_{2}$ are the singular values for the first principal component (PC1) and second principal component (PC2), respectively; $\xi_{1}$ and $\xi_{2}$ are eigenvectors of the $i^{\text {th }}$ genotype for PC1 and PC2, respectively. The components $\eta_{j 1}$ and $\eta_{j 2}$ are eigenvectors of the $j^{\text {th }}$ trait for the principal components PC1 and PC2, respectively; $S_{j}$ is the phenotypic standard deviation of the $j^{\text {th }}$ trait, and $\varepsilon_{i j}$ is the residual associated with the combination of the $i^{\text {th }}$ genotype and the $j^{\text {th }}$ trait.

\section{Results}

\subsection{Analysis of Variance}

Combined analysis of variance across all the environments in which the traits were observed revealed that environment and genotype effects were significant for majority of traits (Table 3). Genotype-by-environment interaction effects were not significant for most of the traits, except for days to physiological maturity (DTM), tassel size (TS) and grain yield (GY) (Table 3). The mean performance of the twelve inbred lines for various traits across all environments is shown in Table 4.

\subsection{Genotype by Trait Analysis}

The genotype by trait biplots, Figures 1 and 2 show how the genotypes performed in respect of particular traits under managed drought and across all the environments, respectively. Genotypes that are associated or are in the same sector with particular traits were the best performers for those traits. Vertex genotypes are either the best or the worst in terms of expression of particular traits. The results of genotype by trait biplot analysis across all the environments are substantiated by mean performance data for the genotypes across environments presented in Table 4.

Under managed drought, the genotype by trait biplot (Figure 1) accounted for a total of $55.43 \%$ of the total variation in the standardized data set, which was partitioned as follows: $34.99 \%$ explained by the first principal component (PC1) and $20.43 \%$ explained by the second principal component (PC2). Easily noticeable associations were between genotypes G6 (DMR-M-88) and G8 (M39) with high levels in grain filling duration (GFD), kernel row number (KRN), kernels per ear row (KER), kernels per ear (KPE), ears per plant (EPP), kernel weight per ear (KWE), and low levels in drought susceptibility index (DSI), days to anthesis (AD), days to silking (SD) and days to physiological maturity (DTM). Genotypes G3 (FA6) and G7 (DMR-M-84) were found to be associated with high values for grain yield (GY) and plant height (PH), and also low values for drought susceptibility index (DSI). Further, under the same environmental conditions, genotypes G1 (DMR-M-81) and G5 (GPM36) were associated with high levels in ear diameter (ED), ear height (EH), and low levels in ear aspect (EA), leaf senescence (LS) and leaf rolling (LR). Genotype G4 (DMR-M-83) was associated with a constellation of undesirable attributes, viz. high values in drought susceptibility index (DSI), lodging (LOD), ear aspect (EA) and leaf rolling (LR).

Across all the seven evaluation environments, genotype-by-trait analysis revealed associations as presented in Figure 2. The first principal component (PC1) explained 38.42\% of the of the standardized data set, and the second principal component explained $21.50 \%$ of the variation, while both the PC components accounted for $59.91 \%$ of the variation. Genotypes G3 (FA6), G5 (GPM36), G6 (DMR-M-88), and G7 (DMR-M-84) were strongly associated with kernels per ear (KPE), kernels per ear row (KER), ear length (EL), kernel row number (KRN), plant height (PH), and grain yield (GY). Genotypes G1 (DMR-M-81), G2 (M4), and G9 (M53) were associated with high values in ear diameter (ED), days to anthesis (AD), days to silking (DS), days to physiological maturity (DTM), and low values in lodging (LOD) and ear aspect (EA). 
Table 3. Mean sum of squares from analysis of variance for traits of twelve inbred lines evaluated across diverse environments

\begin{tabular}{|c|c|c|c|c|c|c|c|c|c|c|c|c|}
\hline \multirow{2}{*}{ Character } & \multicolumn{2}{|c|}{ Environment (E) } & \multicolumn{2}{|c|}{ Replication (R) in (E) } & \multicolumn{2}{|c|}{ Block $(E \times R)$} & \multicolumn{2}{|c|}{ Genotype (G) } & \multicolumn{2}{|r|}{$\mathrm{G} \times \mathrm{E}$} & \multicolumn{2}{|r|}{ Error } \\
\hline & DF & MS & DF & MS & $\mathrm{DF}$ & MS & DF & MS & DF & MS & DF & MS \\
\hline Days to anthesis & 6 & $964.25^{* * *}$ & 7 & $6.95^{*}$ & 28 & 2.65 & 11 & $22.56^{* * *}$ & 66 & 1.90 & 49 & 2.76 \\
\hline Days to silking & 6 & $1291.69 * * *$ & 7 & $10.85^{*}$ & 28 & 4.62 & 11 & $34.01 * * *$ & 66 & 2.76 & 49 & 4.07 \\
\hline Anthesis-silking interval & 6 & $3.24 * * *$ & 7 & 0.001 & 28 & 0.002 & 11 & $0.004 *$ & 66 & 0.002 & 49 & 0.002 \\
\hline Days to physiological maturity & 6 & $1291.12 * * *$ & 7 & 4.06 & 28 & 2.42 & 11 & $23.79 * * *$ & 66 & $4.85^{*}$ & 49 & 2.59 \\
\hline Grain filling duration & 6 & $2236.41 * * *$ & 7 & 3.57 & 28 & 5.39 & 11 & $9.68^{*}$ & 66 & 7.40 & 49 & 4.79 \\
\hline Leaf rolling ${ }^{\mathrm{b}}$ & 1 & $2.23 * * *$ & 2 & $0.21^{*}$ & 8 & 0.06 & 11 & $0.14 * *$ & 11 & 0.16 & 14 & 0.03 \\
\hline Leaf senescence & 1 & $2.34 * * *$ & 2 & 0.14 & 8 & 0.07 & 11 & 0.07 & 11 & 0.06 & 14 & 0.04 \\
\hline Plant height $(\mathrm{cm})$ & 6 & $14395.58 * * *$ & 7 & $313.23 * * *$ & 28 & $113.64 *$ & 11 & $352.95 * *$ & 66 & 91.61 & 49 & 64.38 \\
\hline Ear height $(\mathrm{cm})$ & 6 & $3701.81 * * *$ & 7 & $162.46^{* * *}$ & 28 & $59.42 *$ & 11 & $139.34 * * *$ & 66 & 47.65 & 49 & 30.70 \\
\hline Tassel size & 6 & $0.43 * * *$ & 7 & 0.01 & 28 & $0.02 * * *$ & 11 & $0.12 * * *$ & 66 & $0.02 * * *$ & 49 & 0.01 \\
\hline Lodging & 6 & $1.68 * * *$ & 7 & 0.05 & 28 & 0.05 & 11 & $0.19 * * *$ & 66 & 0.06 & 49 & 0.03 \\
\hline Ears per plant & 6 & $1.93 * * *$ & 7 & $0.06^{*}$ & 28 & 0.03 & 11 & 0.01 & 66 & 0.03 & 49 & 0.16 \\
\hline Ear aspect & 6 & $0.99 * * *$ & 7 & $0.12 * *$ & 28 & 0.05 & 11 & $0.34 * * *$ & 66 & 0.11 & 49 & 0.04 \\
\hline Ear length & 6 & $175.72 * * *$ & 7 & 1.92 & 28 & 1.51 & 11 & 2.73 & 66 & 1.87 & 49 & 1.62 \\
\hline Ear diameter & 6 & $3.13^{* * *}$ & 7 & 0.15 & 28 & 0.06 & 11 & $0.51^{* * *}$ & 66 & 0.14 & 49 & 0.08 \\
\hline Kernel row number & 6 & $6.92 * * *$ & 7 & 1.08 & 28 & 0.49 & 11 & $2.85^{* *}$ & 66 & 1.02 & 49 & 1.05 \\
\hline Kernels per ear row & 6 & $565.36^{* * *}$ & 7 & $23.30^{*}$ & 28 & 6.84 & 11 & 25.56 & 66 & 15.86 & 49 & 10.49 \\
\hline Kernels per ear & 6 & $123545.83 * * *$ & 7 & $7282.45^{*}$ & 28 & 1981.92 & 11 & $9354.21 * *$ & 66 & 4285.92 & 49 & 3261.54 \\
\hline Kernel weight per ear (g) & 6 & $30573.70^{* * *}$ & 7 & $1150.63 * * *$ & 28 & 205.24 & 11 & $671.23 * *$ & 66 & 334.25 & 49 & 233.60 \\
\hline Grain yield $\left(\mathrm{t} \mathrm{ha}^{-1}\right)$ & 6 & $154.23 * * *$ & 7 & $5.08 * * *$ & 28 & 1.41 & 11 & $4.53 * * *$ & 66 & $2.07 * *$ & 49 & 1.01 \\
\hline Drought susceptibility index & 1 & 0.01 & 2 & $0.12 * *$ & 8 & $0.05^{*}$ & 11 & $0.04 *$ & 11 & 0.03 & 14 & 0.01 \\
\hline
\end{tabular}

Note. ${ }^{*} \mathrm{P} \leq 0.05,{ }^{* *} \mathrm{P} \leq 0.01,{ }^{* * *} \mathrm{P} \leq 0.001 ; \mathrm{DF}=$ Degrees of freedom; $\mathrm{MS}=$ Mean squares. ${ }^{\mathrm{b}}$ Leaf rolling and leaf senescence were observed only under drought situation.

Table 4. The least square means (LSMEANS) with respect to grain yield and secondary traits of twelve inbred lines evaluated across different growing environments

\begin{tabular}{|c|c|c|c|c|c|c|c|c|c|c|c|c|}
\hline Code & Name & $\begin{array}{l}\text { Days to } \\
\text { anthesis }\end{array}$ & $\begin{array}{l}\text { Days to } \\
\text { silking }\end{array}$ & $\begin{array}{l}\text { Anthesis- } \\
\text { Silking } \\
\text { Interval } \\
\text { (days) }\end{array}$ & $\begin{array}{l}\text { Days to } \\
\text { physiological } \\
\text { maturity }\end{array}$ & $\begin{array}{l}\text { Grain filling } \\
\text { duration } \\
\text { (days) }\end{array}$ & $\begin{array}{l}\text { Leaf } \\
\text { rolling }\end{array}$ & $\begin{array}{l}\text { Leaf } \\
\text { senescence }\end{array}$ & $\begin{array}{l}\text { Drought } \\
\text { susceptibility } \\
\text { index }\end{array}$ & $\begin{array}{l}\text { Plant } \\
\text { height } \\
(\mathrm{cm})\end{array}$ & $\begin{array}{l}\text { Ear } \\
\text { height } \\
(\mathrm{cm})\end{array}$ & $\begin{array}{l}\text { Tassel } \\
\text { size }\end{array}$ \\
\hline G1 & DMR-M-81 & $68.17 \mathrm{a}$ & $71.21 \mathrm{a}$ & $3.05 \mathrm{a}$ & $106.12 \mathrm{a}$ & $34.90 \mathrm{ab}$ & $3.29 \mathrm{ab}$ & 4.92 & $1.06 \mathrm{a}$ & $139.38 \mathrm{ab}$ & $66.94 a-c$ & $3.65 \mathrm{ab}$ \\
\hline G2 & M4 & $67.45 \mathrm{ab}$ & $69.64 \mathrm{ab}$ & $2.19 \mathrm{ab}$ & $103.12 \mathrm{a}-\mathrm{c}$ & $33.48 b$ & $2.67 \mathrm{~b}$ & 4.79 & $1.23 \mathrm{a}$ & $135.37 \mathrm{ab}$ & $66.35 \mathrm{a}-\mathrm{c}$ & $3.33 \mathrm{a}-\mathrm{c}$ \\
\hline G3 & FA6 & $66.17 \mathrm{a}-\mathrm{c}$ & $68.64 \mathrm{ab}$ & $2.48 \mathrm{ab}$ & $103.26 a-c$ & $34.62 \mathrm{ab}$ & $2.29 \mathrm{ab}$ & 5.42 & $0.91 \mathrm{a}$ & $139.19 \mathrm{ab}$ & $68.69 \mathrm{ab}$ & $3.30 \mathrm{bc}$ \\
\hline G4 & DMR-M-83 & $65.74 a-c$ & $67.64 \mathrm{ab}$ & $1.90 \mathrm{ab}$ & $101.62 \mathrm{c}$ & $33.98 b$ & $4.92 \mathrm{a}$ & 7.29 & $1.16 \mathrm{a}$ & $126.35 b$ & $62.09 \mathrm{a}-\mathrm{c}$ & $2.69 \mathrm{de}$ \\
\hline G5 & GPM36 & $64.63 \mathrm{bc}$ & $66.57 b c$ & $1.94 \mathrm{ab}$ & $101.72 b c$ & $35.15 \mathrm{ab}$ & $2.91 \mathrm{ab}$ & 5.31 & $1.03 \mathrm{a}$ & $143.95 \mathrm{a}$ & $71.36 \mathrm{a}$ & $3.91 \mathrm{a}$ \\
\hline G6 & DMR-M-88 & $64.13 \mathrm{c}$ & $66.14 b c$ & $2.02 \mathrm{ab}$ & $101.52 \mathrm{c}$ & $35.37 \mathrm{ab}$ & $3.68 \mathrm{ab}$ & 5.52 & $0.93 \mathrm{a}$ & $138.59 \mathrm{ab}$ & 63.63a-c & $3.26 \mathrm{bc}$ \\
\hline G7 & DMR-M-84 & $64.45 \mathrm{bc}$ & $67.50 \mathrm{bc}$ & $3.05 \mathrm{ab}$ & $102.76 b c$ & $35.26 \mathrm{ab}$ & $2.54 \mathrm{ab}$ & 5.42 & $1.07 \mathrm{a}$ & $132.97 \mathrm{ab}$ & $66.45 \mathrm{a}-\mathrm{c}$ & $3.87 \mathrm{a}$ \\
\hline G8 & M39 & $65.45 \mathrm{a}-\mathrm{c}$ & $66.43 \mathrm{bc}$ & $0.98 \mathrm{ab}$ & $102.12 b c$ & $35.69 \mathrm{ab}$ & $3.04 \mathrm{ab}$ & 4.54 & $0.92 \mathrm{a}$ & $137.29 \mathrm{ab}$ & $63.19 \mathrm{a}-\mathrm{c}$ & $2.58 \mathrm{e}$ \\
\hline G9 & M53 & $67.89 \mathrm{a}$ & $69.43 \mathrm{ab}$ & $1.54 \mathrm{ab}$ & $104.04 \mathrm{a}-\mathrm{c}$ & $34.61 \mathrm{ab}$ & $3.01 \mathrm{ab}$ & 5.61 & $0.90 \mathrm{a}$ & $127.04 \mathrm{~b}$ & $68.81 \mathrm{a}$ & $3.13 b c$ \\
\hline G10 & FA3 & $65.80 \mathrm{a}-\mathrm{c}$ & $67.86 \mathrm{ab}$ & $2.06 \mathrm{ab}$ & $104.27 \mathrm{ab}$ & $36.41 \mathrm{ab}$ & $3.20 \mathrm{ab}$ & 5.10 & $1.17 \mathrm{a}$ & $125.37 \mathrm{~b}$ & $59.16 b c$ & $3.00 \mathrm{~cd}$ \\
\hline G11 & GPM43 & 65.96a-c & $67.64 a-c$ & $1.68 \mathrm{ab}$ & $103.04 \mathrm{a}-\mathrm{c}$ & $35.40 \mathrm{ab}$ & $3.26 \mathrm{ab}$ & 6.23 & $1.16 \mathrm{a}$ & $132.53 \mathrm{ab}$ & $60.60 \mathrm{bc}$ & $2.91 \mathrm{~cd}$ \\
\hline G12 & GPM53 & $64.30 \mathrm{c}$ & $64.64 \mathrm{c}$ & $0.34 \mathrm{bab}$ & $101.84 \mathrm{bc}$ & $37.20 \mathrm{a}$ & $3.70 \mathrm{ab}$ & 6.22 & $0.97 \mathrm{a}$ & $124.16 b$ & $57.37 \mathrm{c}$ & $3.00 \mathrm{~cd}$ \\
\hline Mean & & 65.845 & 67.780 & 1.935 & 102.952 & 35.173 & 3.208 & 5.531 & 1.042 & 133.517 & 64.553 & 3.220 \\
\hline SEm & & 0.138 & 0.582 & 0.378 & 0.464 & 0.632 & 0.179 & 0.282 & 0.033 & 2.316 & 2.466 & 0.084 \\
\hline$P$-value & & $<.0001$ & $<.0001$ & 0.0339 & $<.0001$ & 0.0465 & 0.0083 & 0.1432 & 0.0317 & $<.0001$ & 0.0001 & $<.0001$ \\
\hline$C V(\%)$ & & 2.523 & 2.975 & 3.269 & 1.563 & 6.223 & 14.833 & 11.965 & 11.135 & 6.010 & 8.583 & 6.423 \\
\hline
\end{tabular}


Table 4. Continued

\begin{tabular}{|c|c|c|c|c|c|c|c|c|c|c|c|}
\hline Code & Name & Lodging & $\begin{array}{l}\text { Ears per } \\
\text { plant }\end{array}$ & $\begin{array}{l}\text { Ear } \\
\text { aspect }\end{array}$ & $\begin{array}{l}\text { Ear } \\
\text { length }\end{array}$ & $\begin{array}{l}\text { Ear } \\
\text { diameter }\end{array}$ & $\begin{array}{l}\text { Kernel row } \\
\text { number }\end{array}$ & $\begin{array}{l}\text { Kernels per } \\
\text { ear row }\end{array}$ & $\begin{array}{l}\text { Kernels } \\
\text { per ear }\end{array}$ & $\begin{array}{l}\text { Kernel weight } \\
\text { per ear }\end{array}$ & $\begin{array}{l}\text { Grain yield } \\
\left(\mathrm{t} \mathrm{ha}^{-1}\right)\end{array}$ \\
\hline G1 & DMR-M-81 & $1.00 \mathrm{c}$ & 0.66 & $2.35 \mathrm{a}-\mathrm{c}$ & 12.20 & $4.15 \mathrm{a}-\mathrm{c}$ & $13.58 \mathrm{a}$ & $25.76 a$ & $353.10 \mathrm{a}$ & $72.41 \mathrm{ab}$ & $3.46 \mathrm{ab}$ \\
\hline G2 & M4 & $2.14 \mathrm{a}-\mathrm{c}$ & 0.68 & $1.90 \mathrm{c}$ & 11.81 & $4.16 \mathrm{ab}$ & $14.11 \mathrm{a}$ & $27.26 \mathrm{a}$ & $383.48 \mathrm{a}$ & $83.50 \mathrm{a}$ & $4.48 \mathrm{ab}$ \\
\hline G3 & FA6 & $1.04 \mathrm{c}$ & 0.74 & $2.14 b c$ & 13.14 & $3.92 \mathrm{a}-\mathrm{c}$ & $13.37 \mathrm{a}$ & $28.56 \mathrm{a}$ & $384.77 \mathrm{a}$ & $79.72 \mathrm{ab}$ & $3.91 \mathrm{ab}$ \\
\hline G4 & DMR-M-83 & $2.39 \mathrm{a}$ & 0.62 & $3.58 \mathrm{a}$ & 11.58 & $3.60 \mathrm{c}$ & $13.32 \mathrm{a}$ & $25.57 \mathrm{a}$ & $341.60 \mathrm{a}$ & $63.10 \mathrm{~b}$ & $2.76 b$ \\
\hline G5 & GPM36 & $2.16 \mathrm{ab}$ & 0.67 & $1.90 \mathrm{c}$ & 13.03 & $4.13 \mathrm{a}-\mathrm{c}$ & $14.00 \mathrm{a}$ & $28.98 \mathrm{a}$ & $407.73 a$ & $90.76 \mathrm{a}$ & $4.55 \mathrm{a}$ \\
\hline G6 & DMR-M-88 & $1.56 \mathrm{a}-\mathrm{c}$ & 0.76 & $2.87 \mathrm{a}-\mathrm{c}$ & 12.89 & $4.19 \mathrm{ab}$ & $14.12 \mathrm{a}$ & $28.98 \mathrm{a}$ & $410.29 a$ & $82.44 \mathrm{ab}$ & $4.50 \mathrm{ab}$ \\
\hline G7 & DMR-M-84 & $2.18 \mathrm{ab}$ & 0.68 & $3.28 \mathrm{ab}$ & 12.82 & $3.85 \mathrm{a}-\mathrm{c}$ & $14.59 \mathrm{a}$ & $29.43 a$ & $428.75 a$ & $69.49 \mathrm{ab}$ & $3.39 \mathrm{ab}$ \\
\hline G8 & M39 & $2.14 \mathrm{a}-\mathrm{c}$ & 0.71 & $2.24 b c$ & 12.34 & $4.06 \mathrm{a}-\mathrm{c}$ & $13.46 \mathrm{a}$ & $28.45 \mathrm{a}$ & $382.50 \mathrm{a}$ & $79.04 \mathrm{ab}$ & $3.73 \mathrm{ab}$ \\
\hline G9 & M53 & $1.92 \mathrm{a}-\mathrm{c}$ & 0.66 & $2.37 b c$ & 11.58 & $4.28 \mathrm{a}$ & $13.06 \mathrm{a}$ & $24.70 \mathrm{a}$ & $329.45 a$ & $73.43 \mathrm{ab}$ & $3.46 \mathrm{ab}$ \\
\hline G10 & FA3 & $1.58 \mathrm{bc}$ & 0.67 & $2.63 a-c$ & 11.52 & $4.07 \mathrm{a}-\mathrm{c}$ & $13.12 \mathrm{a}$ & $26.25 \mathrm{a}$ & $349.04 \mathrm{a}$ & $72.10 \mathrm{ab}$ & $3.36 \mathrm{ab}$ \\
\hline G11 & GPM43 & $2.17 \mathrm{a}-\mathrm{c}$ & 0.69 & $2.94 \mathrm{ab}$ & 12.60 & $3.80 \mathrm{bc}$ & $13.96 \mathrm{a}$ & $26.61 \mathrm{a}$ & $375.64 a$ & $74.89 \mathrm{ab}$ & $3.18 \mathrm{ab}$ \\
\hline G12 & GPM53 & $1.97 \mathrm{a}-\mathrm{c}$ & 0.69 & $2.60 \mathrm{a}-\mathrm{c}$ & 12.41 & $3.89 \mathrm{a}-\mathrm{c}$ & $13.10 \mathrm{a}$ & $28.30 \mathrm{a}$ & $368.00 \mathrm{a}$ & $73.35 \mathrm{ab}$ & $3.08 \mathrm{ab}$ \\
\hline Mean & & 1.854 & 0.686 & 2.568 & 12.326 & 4.009 & 13.648 & 27.404 & 376.195 & 76.186 & 3.656 \\
\hline$S E m$ & & 0.158 & 0.047 & 0.174 & 0.367 & 0.084 & 0.296 & 0.935 & 16.486 & 4.412 & 0.291 \\
\hline$P$-value & & $<.0001$ & 0.8680 & $<.0001$ & 0.1051 & $<.0001$ & 0.0082 & 0.0164 & 0.0056 & 0.0055 & 0.0001 \\
\hline$C V(\%)$ & & 16.537 & 23.561 & 16.121 & 10.327 & 7.247 & 7.511 & 11.818 & 15.181 & 20.062 & 27.533 \\
\hline
\end{tabular}

Note. Means followed by the same letter(s) within a column are not significantly different at $5 \%$ level of significance.

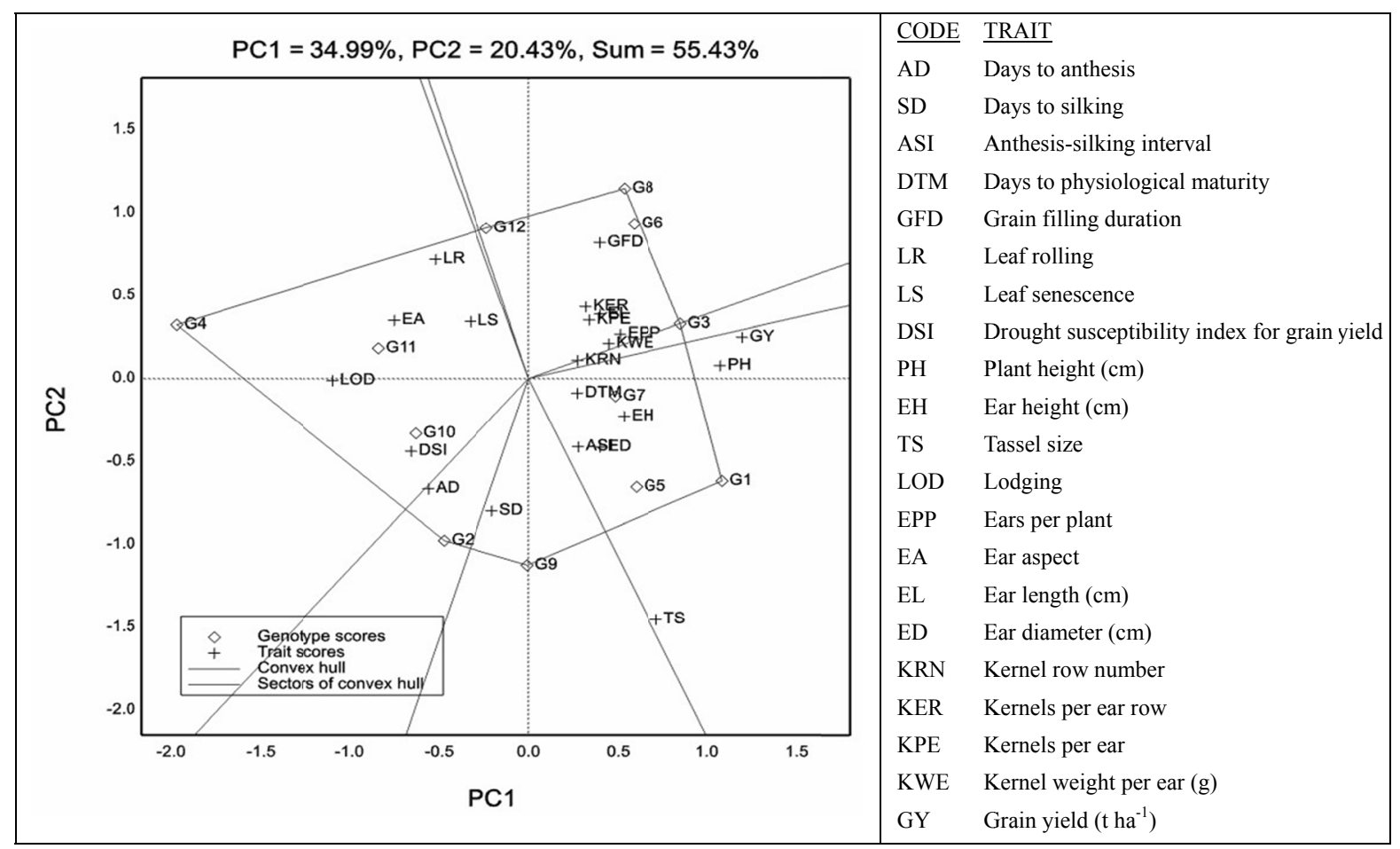

Figure 1. A polygon view genotype-by-trait biplot showing 12 tropical maize inbred lines and 21 traits observed under managed drought environments over two seasons. Genotypes are represented by diamond shaped markers and traits are represented by plus signs. Genotype codes are explained in Table 1 and in the text 


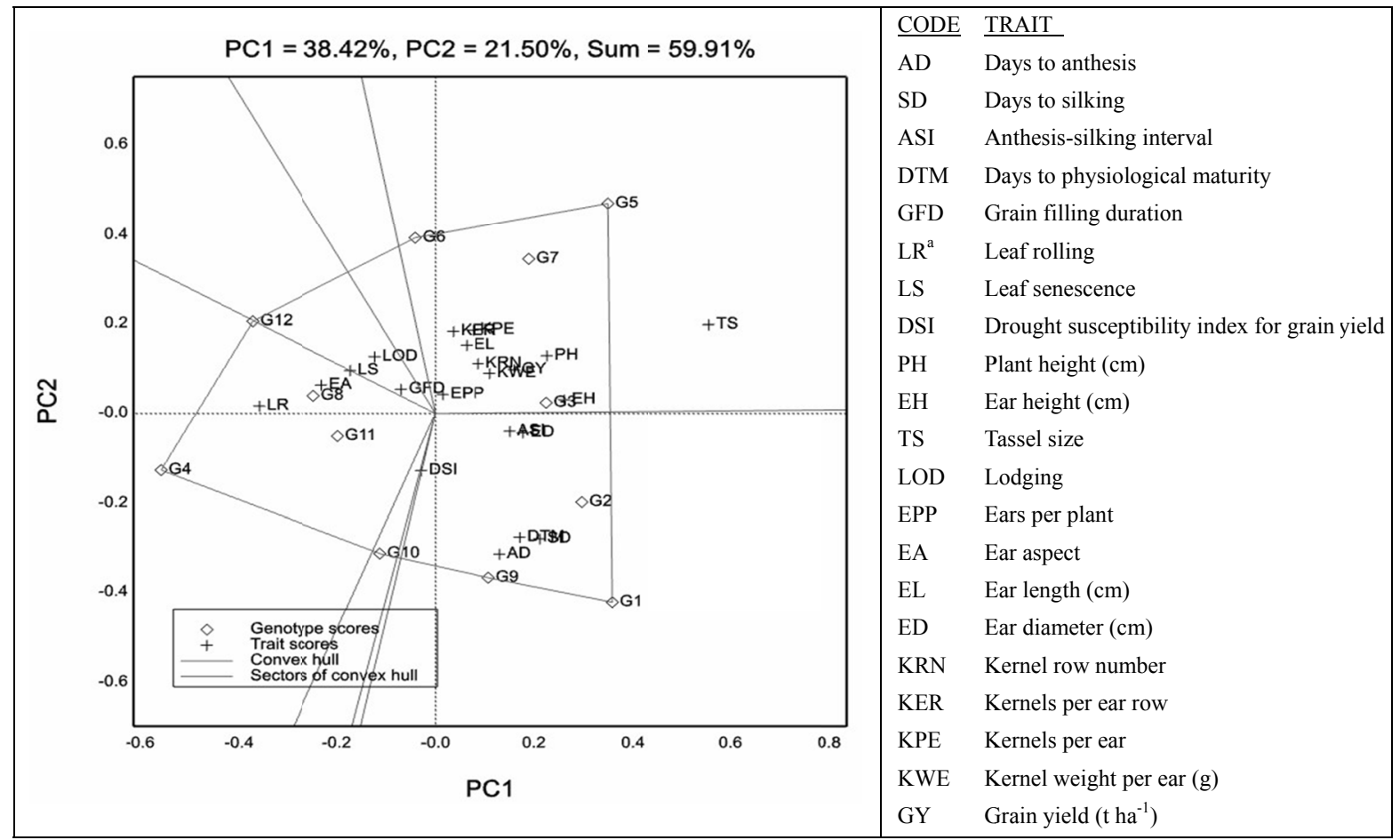

Figure 2. A polygon view genotype-by-trait biplot showing 12 tropical maize inbred lines and 21 traits observed across seven diverse environments. Genotypes are represented by diamond shaped markers and traits are represented by plus signs. Genotype codes are explained in Table 1 and in the text

Note. ${ }^{a}$ LR and LS were observed only under managed drought.

\section{Discussion}

\subsection{Analysis of Variance}

Significance of environmental effects implies that the level of expression of traits across the environments was different. Significant genotypic effects suggest that the inbred lines possess different allelic combinations for expression of the traits. The genotypes responded differently in regard to expression of DTM, TS, and GY across environments; however for majority of traits, responses of genotypes were the same across environments.

\subsection{Genotype by Trait Analysis}

The genotype by trait biplot can offer visual comparison of genotypes for multiple traits, since trait profiles especially for genotypes that are located far away from the biplot origin are shown (Yan \& Rajcan, 2002; Yan \& Kang, 2003; Yan \& Frégeau-Reid, 2008).

\subsubsection{Genotype by Trait Analysis under Drought and across Environments}

Genotypes G6 (DMR-M-88) and G8 (M39) were found to be superior in inherent component traits of grain yield viz. kernel row number, kernels per ear row and kernel weight per ear under drought, thus may produce high yielding hybrids if used in hybrid development programmes targeting drought tolerance. This is true if there is a positive correlation between inbred lines and their hybrid progenies in respect of grain yield; however in other studies, for example, Betrán et al. (2003), such a correlation was found to be relatively low. For other traits, for example, ear traits which are potentially involved in grain yield determination, the inbred-hybrid correlation has been found to be relatively high (Betrán et al., 2003; Betrán, Ribaut, Beck, \& Gonzalez De León, 2003; Oyekunle, Badu-Apraku, Hearne, \& Franco, 2015). It remains therefore necessary to carry out a combining ability analysis study in order to observe whether the inbred lines are able to transmit genes for their associated traits to their hybrid offspring. Early maturity, which is one of the characteristics of these inbred lines (DMR-M-88 and M39), is one of the most important attributes for crops exposed to early terminal drought stress (Harrison, Tardieu, Dong, Messina, \& Hammer, 2014), and incorporating this trait in drought tolerance breeding programmes may help stabilize grain yields in farmers' fields. Ears per plant (EPP), which is also associated with these genotypes under drought (Figure 1), is a reliable secondary trait for selection of drought tolerant materials, and high values 
for this trait are desirable (Bänzinger et al., 2000). A low value in drought susceptibility, a feature associated with G3 (FA6) and G7 (DMR-M-84) means these genotypes are drought tolerant as was confirmed by Grzesiak et al. (2012). Low values in leaf senescence (LS) and leaf rolling (LR) as exhibited by genotypes G1 (DMR-M-81) and G5 (GPM36) are some of the traits that are important for identification of drought tolerant materials (Bänzinger et al., 2000). Three genotypes viz. G3 (FA6), G5 (GPM36), G6 (DMR-M-88), and G7 (DMR-M-84) were superior in inherent component traits of grain yield namely, kernel row number, kernels per ear row and kernel weight per ear across environments, thus may produce high yielding hybrids if used in hybrid development programmes targeting adaptation to diverse environments.

\subsubsection{Implications on Selection of Parents}

The GT biplots showed rich information that can be utilized by breeders, especially in selection of parents for a breeding programme aimed at improving particular traits, as was pointed by Yan and Fregeau-Reid (2008), Yan and Kang (2003), and Yan and Rajcan (2002). Under managed drought, genotypes G6 (DMR-M-88), G8 (M39), G3 (F6), G5 (GPM36), and G1 (DMR-M-81) appeared to have good attributes, and would be used as parents in a hybridization programme meant to generate drought tolerant hybrids. Across diverse environments, the genotypes G3 (FA6), G5 (GPM36), G6 (DMR-M-88), and G7 (DMR-M-84), which are associated with grain yield and its inherent component traits could be used as parents in hybrid development programmes targeting stable and high yielding hybrids, as was suggested by Meseka, Menkir and Ibrahim (2008). However, since it is not possible to know the desirability of inbred lines for use as parents based solely on their individual performance (Bertan, Carvalho, \& Oliveira, 2007), the ability of the identified inbred lines to transmit genes for the traits they are associated with to their offspring (combining ability) needs to be evaluated.

The inbred lines such as G3 (FA6), G5 (GPM36), G6 (DMR-M-88), and G7 (DMR-M-84), which are associated with grain yield and its inherent component traits would be desirable if they are used as female parents in hybrid seed production. This assertion is supported by Beck (2002) who highlighted that high seed yield is one of the very important attributes of a female (seed) parent lines in maize hybrid seed production. The lines G3 and G6 also have an added advantage of being good performers under drought (Figure 1), which is another important attribute of a female parent in seed production as emphasized by Frey (1981). As pointed by D'Andrea, Otegui, and De La Vega (2008), in selecting inbred lines for use in a hybrid breeding programme, both agronomic traits and grain yield per se are important. Hallauer and Miranda Filho (1988) further asserted that vigorous and highly productive inbred lines are very important in seed production since they determine the producibility of a hybrid, and decrease the costs of single-cross hybrid seed production. The results of this study should be considered in future breeding programmes involving some or all the inbred lines evaluated.

\section{Acknowledgements}

This work was made possible by the financial support from the All India Coordinated Maize Improvement Project (AICMIP) at University of Agricultural Sciences, Dharwad, India.

\section{References}

Bänziger, M., Edmeades, G. O., Beck, D., \& Bellon, M. (2000). Breeding for drought and nitrogen stress tolerance in maize: From theory to practice (p. 68). Mexico, D. F.: CIMMYT.

Beck, D. L. (2002). Management of Hybrid Maize Seed Production. Mexico, D. F.: CIMMYT.

Bertan, I., Carvalho, F. I. F. de, \& Oliveira, A. A. C. de. (2007). Parental selection strategies in plant breeding programs. Journal of Crop Science and Biotechnology, 10(4), 211-222. Retrieved from http://cropbio.org/contribute/paperfiles/Antonio Costa de Oliveira.pdf

Betrán, F. J., Beck, D., Bänziger, M., \& Edmeades, G. O. (2003). Genetic analysis of inbred and hybrid grain yield under stress and nonstress environments in tropical maize. Crop Science, 43(3), 807-817. https://doi.org/ 10.2135/cropsci2003.08070

Betrán, F. J., Ribaut, J. M., Beck, D., \& Gonzalez De León, D. (2003). Genetic diversity, specific combining ability, and heterosis in tropical maize under stress and nonstress environments. Crop Science, 43(3), 797-806. https://doi.org/10.2135/cropsci2003.07970

Chen, J., Xu, W., Velten, J., Xin, Z., \& Stout, J. (2012). Characterization of maize inbred lines for drought and heat tolerance. Journal of Soil and Water Conservation, 67(5), 354-364. https://doi.org/10.2489/jswc.67.5.354

D’Andrea, K. E., Otegui, M. E., \& De La Vega, A. J. (2008). Multi-attribute responses of maize inbred lines across managed environments. Euphytica, 162, 381-394. https://doi.org/10.1007/s10681-007-9567-3 
Edmeades, G. O. (2013). Progress in achieving and delivering drought tolerance in maize-An update. The International Service for the Acquisition of Agri-Biotech Applications (ISAAA): Ithaca, NY.

Frey, N. M. (1981). Environmental influences on corn seed quality and production. In J. Burris (Ed.), Proceedings of the 4th Ann. Seed Technology Conference (pp. 71-80). Ames, Iowa: Seed Science Center.

Grzesiak, M. T., Waligorski, P., Janowiak, F., Marcinska, I., Hura, K., Szczyrek, P., \& Glab, T. (2013). The relations between drought susceptibility index based on grain yield (DSIGY) and key physiological seedling traits in maize and triticale genotypes. Acta Physiologiae Plantarum, 35(2), 549-565. https://doi.org/10.1007/ s11738-012-1097-5

Hallauer, A. R., \& Miranda Filho, J. B. (1988). Quantitative genetics in maize breeding. Ames: Iowa State University Press.

Harrison, M. T., Tardieu, F., Dong, Z., Messina, C. D., \& Hammer, G. L. (2014). Characterizing drought stress and trait influence on maize yield under current and future conditions. Global Change Biology, 20(3), 867-878. https://doi.org/10.1111/gcb.12381

Kirkham, M. B., Suksayretrup, K., Wassom, C. E., \& Kanemasu, E. T. (1984). Canopy temperature of drought-resistant and drought-sensitive genotypes of maize. Maydica, 29(3), 287-303.

Meseka, S. K., Menkir, A., \& Ibrahim, A. E. S. (2008). Yield stability of maize inbred lines with differential reactions to drought evaluated under stress and non-stress environments. Gezira Journal of Agricultural Sciences, 6(2), 182-195.

Meseka, S. K., Menkir, A., Ibrahim, A. E. S., \& Ajala, S. O. (2013). Genetic analysis of maize inbred lines for tolerance to drought and low nitrogen. Journal of Natural Resources and Environmental Studies, 1(June), 29-36.

Oladejo, A. S., Akinwale, R. O., \& Obisesan, I. O. (2011). Interrelationships between grain yield and other physiological traits of cowpea cultivars. African Crop Science Journal, 19(3), 189-200.

Oyekunle, M., Badu-Apraku, B., Hearne, S., \& Franco, J. (2015). Genetic diversity of tropical early-maturing maize inbreds and their performance in hybrid combinations under drought and optimum growing conditions. Field Crops Research, 170, 55-65. https://doi.org/10.1016/j.fcr.2014.10.005

Payne, R. W., Harding, S. A., Murray, D. A., Soutar, D. M., Baird, D. B., Glaser, A. I., .. Webster, R. (2011). GenStat Release 14 Reference Manual, Part 2 Directives. Hemel Hempstead, UK: VSN International.

Rubio, J., Cubero, J. I., Martín, L. M., Suso, M. J., \& Flores, F. (2004). Biplot analysis of trait relations of white lupin in Spain. Euphytica, 135(2), 217-224. https://doi.org/10.1023/B:EUPH.0000014911.70355.c9

SAS Institute. (2010). SAS System for Windows. SAS institute Inc., Cary, NC, USA.

Yan, W., \& Frégeau-Reid, J. (2008). Breeding line selection based on multiple traits. Crop Science, 48(2), 417-423. https://doi.org/10.2135/cropsci2007.05.0254

Yan, W., \& Kang, M. S. (2003). GGE biplot analysis: A graphical tool for breeders, geneticists, and agronomists. Boca Raton, FL: CRC Press.

Yan, W., \& Rajcan, I. (2002). Biplot analysis of test sites and trait relations of soybean in Ontario. Crop Science, 42(1), 11-20. https://doi.org/10.2135/cropsci2002.1100

Yan, W., \& Tinker, N. A. (2006). Biplot analysis of multi-environment trial data: Principles and applications. Canadian Journal of Plant Science, 86(3), 623-645. https://doi.org/10.4141/P05-169

Yan, W., Hunt, L. A., Sheng, Q., \& Szlavnics, Z. (2000). Cultivar evaluation and mega-environment investigation based on the GGE biplot. Crop Science, 40(3), 597-605. https://doi.org/10.2135/cropsci2000.403597x

\section{Copyrights}

Copyright for this article is retained by the author(s), with first publication rights granted to the journal.

This is an open-access article distributed under the terms and conditions of the Creative Commons Attribution license (http://creativecommons.org/licenses/by/4.0/). 